\title{
Trichodina heterodentata (Ciliophora: Trichodinidae): a new parasite for Piaractus mesopotamicus (Pisces: Characidae)
}

\author{
SANTIAGO BENITES DE PÁDUA ${ }^{1}$, MAURÍCIO LATERÇA MARTINS ${ }^{2}$, SILVIA PATRÍCIA CARRASCHI ${ }^{1,3}$, \\ CLAUDINEI DA CRUZ ${ }^{3} \&$ MÁRCIA MAYUMI ISHIKAWA ${ }^{4}$ \\ ${ }^{1}$ UNESP Aquaculture Center, CAUNESP, Via de acesso prof. Paulo Donato Castellane, s/n, CEP: 14.884-900, Jaboticabal, SP, Brazil. \\ E-mail: santiagopadua@live.com \\ ${ }^{2}$ AQUOS - Aquatic Organims Health Laboratory, Aquaculture Department, Federal University of Santa Catarina, Rod. Admar Gon- \\ zaga, 1346, CEP: 88040-900, Florianópolis, SC, Brazil.E-mail: mlaterca@cca.ufsc.br \\ ${ }^{3}$ Weed Environmental Research and Studies of the College of Agricultural and Veterinary Sciences at Unesp, Jaboticabal, SP, Brazil. \\ E-mail: pacarraschi@yahoo.com.br;.cruzcl@yahoo.com \\ ${ }^{4}$ Embrapa Western Agriculture, Brazilian Agricultural Research Corporation, EMBRAPA, BR 163, km 253.6, CEP: 79804-970, \\ Dourados, MS, Brazil.E-mail: marcia@cpao.embrapa.br
}

\begin{abstract}
Trichodinids are mobile peritrichous ciliated protozoa, and widely known as ectocommensals and/or parasites of fish and other aquatic organisms. Little is known about the trichodinid fauna in Brazilian fish. This study reports Trichodina heterodentata Duncan, 1977 as a new parasite for freshwater fish Piaractus mesopotamicus Holmberg, 1887. This is the first record of this trichodinid in southeastern Brazil. Fifty specimens impregnated with $2 \%$ silver nitrate and another fifty stained with Giemsa were used for morphometry on the taxonomic characteristics. T. heterodentata in this study is medium size, with a disc-shaped body measuring 49.0 to $61.0 \mu \mathrm{m}$, parasitizing the skin, fins and gills of pacu. Measurement comparisons between the present material and other records from different countries are presented.
\end{abstract}

Key words: Trichodinids, fish ectoparasite, aquaculture health

\section{Introduction}

Trichodinids are mobile peritrichous protozoa that present widespread distribution around the world. They often act as ectocommensals and are capable of establishing ecological relationships with mollusks (Pinto et al. 2006), crustaceans (Silva et al. 2009), fish (Martins et al. 2010) and amphibians (Dias et al. 2009). Some trichodinids can cause harmful effects on their hosts, and they act as parasites of importance in aquaculture that are capable of causing losses through mortality (Khan 2009) and diminished productive performance (Ekanem \& Obiekezie 1996), as well as making the hosts susceptible to other infectious diseases like streptococcosis (Evans et al. 2007) and influencing the efficacy of vaccines (Martins et al. 2011).

Epithelial proliferation on the skin and gills is the main histopathological change caused by trichodinid infestation (Huh et al. 2005; Yemmen et al. 2011), and this may be associated with fusion of the secondary lamellae of the gill filaments and accumulation of mucus (Yemmen et al. 2011), along with destruction of the secondary lamellae (Schalch et al. 2006). Together, these structural disorders in the gill tissue cause respiratory deficit because of the obstruction that comes with tissue death, and this may cause asphyxia and culminate in mortality.

Among the trichodinids, Trichodina heterodentata is a cosmopolitan species and, since it was first described by Duncan (1977), more than 35 species of fishes in 14 families have now been recognized as hosts for this parasite (Martins et al. 2010). In South America, this parasite was first recorded in Venezuela (Van As \& Basson 1989), and it has recently been recorded in Brazil (Dias et al. 2009; Martins et al. 2010) and Peru (Miranda et al. 2012). However, it possibly originated from the African continent and has been dispersed to other countries together with shipments of cichlids destined for aquaculture (Van As \& Basson 1989). 